\title{
Relationship between Carotid Artery Intima- Media Thickness and Choroidal, and Ganglion Cell- Inner Plexiform Layer Thickness
}

\author{
Sinan B ${ }^{1}$, Ercüment $C^{2 *}$, Eyup $\mathrm{K}^{3}$ and Sami Toyran ${ }^{4}$ \\ ${ }^{1}$ Department of Ophthalmology, Medifema Hospital, Turkey \\ ${ }^{2}$ Department of Opthalmolgy, Akhisar State Hospital, Turkey \\ ${ }^{3}$ Department of Ophthalmology, Yüzüncü Yll University, Turkey \\ ${ }^{4}$ Westeye Hospital, Turkey
}

Submission: June 10, 2017; Published: August 23, 2017

*Corresponding author: Ercüment Cavdar, Akhisar State Hosptal, Department of opthalmology, Akhisar, Manisa, Turkey, Tel: (90)5061375203; Fax: +902322324644; Email: 1979erc@gmail.com

\begin{abstract}
Background and objective: To assess the relationship between common carotid artery intima-media thickness (CIMT) and the choroidal, and ganglion cell - inner plexiform layer (GCIPL) thickness.

Materials and methods: This cross-sectional study comprised 50 patients with cardiovascular disorder. CIMT, choroidal thickness thickness at subfoveal, perifoveal and peripapillary locations and GCIPL thickness were measured.

Results: Patients with CIMT value $\geq 0.8 \mathrm{~mm}$ was accepted as group $1(\mathrm{n}=23)$ and $<0.8 \mathrm{~mm}$ was accepted as group 2 (n=27). CIMT was inversely associated with GCIPL thickness and choroidal thickness at all points. However, this relation was not statistically significant for both GCIPL thickness and choroidal thickness except some, random points $(\mathrm{p}<0.05)$.

Conclusion: Although the relationship seems to be weak, these results may support that systemic vascular disorders such as atherosclerosis and cardiovascular disease can lead to structural changes in choroid and retinal ganglion cell layer. Therefore, such diseases should be considered for choroidal structure evaluation.
\end{abstract}

Keywords: Choroidal thickness; Ganglion cell - inner plexiform layer thickness; Carotid artery intima-media thickness; Atherosclerosis

\section{Introduction}

The blood supply to the retina and choroid circulation is mostly provided by the ophthalmic artery which is a branch of the internal carotid artery (ICA). Atherosclerosis is the major factor in producing carotid artery stenosis or occlusion, and carotid artery intima-media thickness (CIMT) is a surrogate marker for the presence and progression of atherosclerosis $[1,2]$. Systemic arterial hypertension is one of the major risk factor for atherosclerosis [3,4]. Also several other factors including age, cholesterol, smoking and diabetes mellitus have been proved to affect the risk of atherosclerosis, and high CIMT values are associated with these risk factors [3,5-7]. In addition to this, hypertension, smoking and diabetes mellitus have been found to be associated with decreasing of choroidal thickness [8-10]. Based on these relationship, we hypothesized that CIMT which is an accepted marker of atherosclerosis may have a relation with choroid and retina. The purpose of this study was, therefore, to assess the relationship between common CIMT and the choroidal, and ganglion cell-inner plexiform layer (GCIPL) thickness.

\section{Materials and Methods}

Fifty subjects referred to radiology department were included in the study. Out of 50 patients, 12 would undergo coronary angiography, 8 would undergo bypass surgery, 6 would undergo cardiac valve surgery and others had myocardial infarction or angina pectoris in their anamnesis. All study participants had best corrected visual acuities of 20/25 or more, a refractive error in the range +3.0 to -3.0 diopters and intraocular pressure (IOP) lower than $21 \mathrm{mmHg}$. Those with systemic or ocular disease (glaucoma, uveitis, high myopia, age-related macular degeneration, diabetes mellitus, etc.) and/or a history of ophthalmic surgery that may have affected the choroidal vascular network were excluded. Measurement of CIMT were made by 
one sonographer, blinded to patient's clinical characteristics and retinal measurements, according to standard recommendations $[11,12]$. The IMT was measured on the far wall of the middle segment of the common carotid artery as the distance between the lumen-intima interface and the media-adventitia interface at $10 \mathrm{~mm}$ proximal to the bifurcation. All participants were examined with Cirrus HD-OCT (Carl Zeiss Meditec, Inc, Dublin, CA). A horizontal and a vertical scan were taken utilizing the high-definition scan protocol which was composed of a single, $6 \mathrm{~mm}$ raster scan consisting of 4096 A-scans. Both scans were taken through the optic nerve and macula. Choroidal thickness was measured perpendicularly from the outer edge of the hyper reflective RPE to the inner sclera at subfoveal area and $500 \mu \mathrm{m}$ intervals temporal, nasal, superior and inferior from the fovea, up to $1500 \mu \mathrm{m}$. Also, peripapillary choroidal thicknesses was measured at the superior, inferior, nasal and temporal quadrants at $500 \mu \mathrm{m}$ intervals, from beginning of the RPE up to $1500 \mu \mathrm{m}$, along the line of the RPE. One of two eyes which had better signal strength was included in the study, and eyes with signal strength lower than 6 were excluded from the study. Scan interpretations and measurements were performed by a blinded investigator. Average GCIPL thicknesses were obtained from retinal OCT scans. All statistical data were analyzed using SPSS version 18.0 (SPSS Inc, Chicago, IL, USA). Values were expressed as mean \pm standard deviation. The normality of the values was analyzed by using Shapiro-Wilk test. Independent samples $t$ test or Mann-Whitney U test was used according to the ShapiroWilk test result. Differences were considered significant at $\mathrm{p}<0.05$. Correlations between the variables were investigated by using Spearman correlation coefficients. The reproducibility of choroidal thickness measurements was calculated via intra class correlation coefficient.

\section{Results}

Patients with CIMT value of at least $0.8 \mathrm{~mm}$ were accepted as group $1(n=23)$ and less than $0.8 \mathrm{~mm}$ were accepted as group $2(\mathrm{n}=27)$. The mean CIMT value was $0.98 \pm 0.3 \mathrm{~mm}$ in group 1 and $0.57 \pm 0.12 \mathrm{~mm}$ in group $2(\mathrm{p}<0.001)$. The mean GCIPL was
$80.17 \pm 9.02$ in group 1 and $83.81 \pm 6.88$ in group $2(p=0.113)$. The rate of hypertensive patients was 18/23 in group 1 and 17/27 in group $2(\mathrm{p}=0.239)$. Differences in age, sex, $A L$, spherical equivalents between the groups were not significant $(p>0.05)$. Table 1 shows demographic and clinical features of the groups. Table 2 shows choroidal thickness measurement differences between group 1 and 2, and also shows the intra class correlation coefficient analysis of the results of the evaluator author at two different time point. Intra class correlation coefficient ranged from 824 to 996 , and these results supported the reliability of the measurements. Subjects in group 1 had thinner choroidal thickness at all parafoveal and peripapillary points. However, the differences between the groups were not statistically significant ( $p>0.05$ ). Table 3 shows correlation analysis results between choroidal thickness and CIMT in all individuals (group 1 plus group 2). There was negative correlation at all points however the differences were not statistically significant at locations $(p>0.05)$. Also there was an insignificant negative correlation between the CIMT and mean GCIPL thickness $(r=-0.233$, $\mathrm{p}=0.103$ ).

Table 1: Demographic and clinical features of the groups. CIMT: Carotid artery Intima-Media Thickness, GCIPL: Ganglion Cell-Inner Plexiform Layer.

\begin{tabular}{|c|c|c|c|}
\hline Parameters & $\begin{array}{c}\text { Group 1 } \\
\text { (N=23) }\end{array}$ & $\begin{array}{c}\text { Group 2 } \\
(\mathbf{N = 2 7})\end{array}$ & P Value \\
\hline Age (years) & $61 \pm 8$ & $58 \pm 4$ & 0.07 \\
\hline Female/male n & $10 / 13$ & $14 / 13$ & 0.555 \\
\hline $\begin{array}{c}\text { Axial length } \\
\text { (mm) }\end{array}$ & $23.2 \pm 0.7$ & $23.06 \pm 0.6$ & 0.335 \\
\hline $\begin{array}{c}\text { Spherical } \\
\text { equivalent } \\
\text { diopter) }\end{array}$ & $0.3 \pm 1.2$ & $-0.4 \pm 1.6$ & 0.119 \\
\hline $\begin{array}{c}\text { Hypertension } \\
\text { n(\%) }\end{array}$ & $18(78 \%)$ & $17(62 \%)$ & 0.239 \\
\hline CIMT (mm) & $0.98 \pm 0.3$ & $0.57 \pm 0.12$ & $<.001 *$ \\
\hline GCIPL & $80.17 \pm 9.02$ & $83.81 \pm 6.88$ & 0.113 \\
\hline
\end{tabular}

*Statistically significant differences; Values are expressed as mean SD.

Table 2: Choroidal thickness measurement differences between the groups, and intraclass correlation coefficient at the same points.

\begin{tabular}{|c|c|c|c|c|c|}
\hline Parameters & Group 1 & Group 2 & $\begin{array}{l}\text { P Value Mann- } \\
\text { Whitney U Test }\end{array}$ & $\begin{array}{c}\text { Intraclass } \\
\text { Correlation } \\
\text { Coefficient }\end{array}$ & P Value \\
\hline $\begin{array}{l}\text { Subfoveal choroidal } \\
\text { thickness }\end{array}$ & $241 \pm 69$ & $248 \pm 77$ & 0.768 & 996 & $<.001$ \\
\hline \multicolumn{6}{|c|}{ Parafoveal choroidal thickness locations } \\
\hline Temporal $500 \mu \mathrm{m}$ & $222 \pm 66$ & $243 \pm 73$ & 0.294 & 981 & $<.001$ \\
\hline Temporal $1000 \mu \mathrm{m}$ & $214 \pm 69$ & $238 \pm 66$ & 0.209 & 971 & $<.001$ \\
\hline Temporal $1500 \mu \mathrm{m}$ & $210 \pm 64$ & $231 \pm 59$ & 0.23 & 956 & $<.001$ \\
\hline Nasal $500 \mu \mathrm{m}$ & $228 \pm 61$ & $238 \pm 81$ & 0.622 & 950 & $<.001$ \\
\hline Nasal $1000 \mu \mathrm{m}$ & $216 \pm 63$ & $238 \pm 77$ & 0.276 & 953 & $<.001$ \\
\hline Nasal $1500 \mu \mathrm{m}$ & $206 \pm 68$ & $223 \pm 70$ & 0.393 & 951 & $<.001$ \\
\hline Superior $500 \mu \mathrm{m}$ & $226 \pm 68$ & $252 \pm 65$ & 0.178 & 960 & $<.001$ \\
\hline Superior $1000 \mu \mathrm{m}$ & $223 \pm 60$ & $246 \pm 58$ & 0.184 & 917 & $<.001$ \\
\hline
\end{tabular}


JOJ Ophthalmology

\begin{tabular}{|c|c|c|c|c|c|}
\hline Superior $1500 \mu \mathrm{m}$ & $215 \pm 63$ & $244 \pm 58$ & 0.106 & 871 & $<.001$ \\
\hline Inferior $500 \mu \mathrm{m}$ & $223 \pm 64$ & $246 \pm 77$ & 0.272 & 950 & $<.001$ \\
\hline Inferir $1000 \mu \mathrm{m}$ & $218 \pm 57$ & $242 \pm 83$ & 0.051 & 943 & $<.001$ \\
\hline Inferior $1500 \mu \mathrm{m}$ & $221 \pm 56$ & $254 \pm 87$ & 0.126 & 925 & $<.001$ \\
\hline \multicolumn{6}{|c|}{ Peripapillary Choroidal thickness locations } \\
\hline Temporal $500 \mu \mathrm{m}$ & $105 \pm 30$ & $125 \pm 38$ & 0.057 & 835 & $<.001$ \\
\hline Temporal $1000 \mu \mathrm{m}$ & $150 \pm 52$ & $173 \pm 56$ & 0.154 & 918 & $<.001$ \\
\hline Temporal $1500 \mu \mathrm{m}$ & $172 \pm 59$ & $202 \pm 71$ & 0.108 & 926 & $<.001$ \\
\hline Nasal $500 \mu \mathrm{m}$ & $123 \pm 58$ & $141 \pm 49$ & 0.477 & 939 & $<.001$ \\
\hline Nasal $1000 \mu \mathrm{m}$ & $159 \pm 71$ & $168 \pm 65$ & 0.142 & 918 & $<.001$ \\
\hline Nasal $1500 \mu \mathrm{m}$ & $171 \pm 68$ & $185 \pm 74$ & 0.485 & 915 & $<.001$ \\
\hline Superior $500 \mu \mathrm{m}$ & $116 \pm 33$ & $134 \pm 39$ & 0.152 & 824 & $<.001$ \\
\hline Superior $1000 \mu \mathrm{m}$ & $150 \pm 48$ & $172 \pm 58$ & 0.156 & 901 & $<.001$ \\
\hline Superior $1500 \mu \mathrm{m}$ & $180 \pm 62$ & $185 \pm 69$ & 0.798 & 936 & $<.001$ \\
\hline Inferior $500 \mu \mathrm{m}$ & $96 \pm 24$ & $116 \pm 42$ & 0.052 & 929 & $<.001$ \\
\hline Inferior $1000 \mu \mathrm{m}$ & $113 \pm 33$ & $133 \pm 48$ & 0.116 & 935 & $<.001$ \\
\hline
\end{tabular}

Table 3: Correlation analysis results between choroidal thickness and carotid intima-media thickness.

\begin{tabular}{|c|c|c|}
\hline Parameters & $\mathbf{R}$ & P Value \\
\hline Subfoveal choroidal thickness & -0.08 & 0.579 \\
\hline \multicolumn{3}{|c|}{ Parafoveal Choroidal thickness locations } \\
\hline Temporal $500 \mu \mathrm{m}$ & -0.241 & 0.091 \\
\hline Temporal $1000 \mu \mathrm{m}$ & -0.252 & 0.078 \\
\hline Temporal $1500 \mu \mathrm{m}$ & -0.303 & $.032 *$ \\
\hline Nasal $500 \mu \mathrm{m}$ & -0.167 & 0.247 \\
\hline Nasal $1000 \mu \mathrm{m}$ & -0.322 & 0.022 \\
\hline Nasal $1500 \mu \mathrm{m}$ & -0.223 & 0.12 \\
\hline Superior $500 \mu \mathrm{m}$ & -0.248 & 0.116 \\
\hline Superior $1000 \mu \mathrm{m}$ & -0.342 & 0.015 \\
\hline Superior $1500 \mu \mathrm{m}$ & -0.29 & 0.086 \\
\hline Inferior $500 \mu \mathrm{m}$ & -0.349 & $.013^{*}$ \\
\hline Inferior $1000 \mu \mathrm{m}$ & -0.211 & 0.063 \\
\hline Inferior $1500 \mu \mathrm{m}$ & -0.216 & 0.076 \\
\hline \multicolumn{3}{|c|}{ Peripapillary choroidal thickness locations } \\
\hline Temporal $500 \mu \mathrm{m}$ & -0.313 & 0.054 \\
\hline Temporal $1000 \mu \mathrm{m}$ & -0.214 & 0.135 \\
\hline Temporal $1500 \mu \mathrm{m}$ & -0.324 & 0.122 \\
\hline Nasal $500 \mu \mathrm{m}$ & -0.334 & $.018^{*}$ \\
\hline Nasal $1000 \mu \mathrm{m}$ & -0.228 & 0.111 \\
\hline Nasal $1500 \mu \mathrm{m}$ & -0.2 & 0.163 \\
\hline Superior $500 \mu \mathrm{m}$ & -0.318 & 0.052 \\
\hline Superior $1000 \mu \mathrm{m}$ & -0.342 & $.015^{*}$ \\
\hline Superior $1500 \mu \mathrm{m}$ & -0.227 & 0.113 \\
\hline Inferior $500 \mu \mathrm{m}$ & -0.263 & 0.066 \\
\hline Inferior $1000 \mu \mathrm{m}$ & -0.326 & $.021^{*}$ \\
\hline Inferior $1500 \mu \mathrm{m}$ & -0.251 & 0.077 \\
\hline
\end{tabular}

*Statistically significant differences; Values are expressed as mean \pm SD. 


\section{Discussion}

Carotid artery stenosis and/or obstruction are most often due to arteriosclerotic vascular disease. CIMT measurement has been used to assess atherosclerosis [1,2]. We demonstrated that patients with high CIMT values had slightly thinner choroidal thickness. Although the relationship seems to be weak CIMT was inversely associated with choroidal thickness in all peripapillary and parafoveal areas. There have been several reports investigating the relationship between ocular structures and carotid vessels [13-17]. Agladioglu et al. [13], found that choroidal thickness was negatively correlated with ICA diameter and ICA resistance index in healthy volunteers. Torres et al. [14], demonstrated that CIMT was inversely associated with retinal arteriolar diameters and directly associated with retinal venular diameters in patients with hypertension. Kang et al. [15], showed a sub foveal thinning of the choroid in three patients with highgrade internal carotid artery stenosis by enhanced depth imaging (EDI) OCT. The relation between ICA and retinal or choroidal circulation may implicate that vascular damage in large arteries might associate with disturbance of microcirculation. High CIMT values may possibly reflect reduced blood flow in choroidal blood vessels that may have an effect on retinal/choroidal function resulting in choroidal thinning and decreasing of ganglion cell thickness. In another study including patients with different degrees of internal carotid artery stenosis, OCT showed thinning of retinal ganglion cell and nerve fiber layers [16]. In the present study, OCT scans revealed slight thinning of the GCIPL thickness. However, GCIPL in different quadrants and retinal nerve fiber layer (RNFL) were not evaluated in this study. We have a few limitations, one of them is small sample size. Also, as RNLF thickness was not measured we could not completely evaluate the relationship between CIMT and retina. Another major drawback was the hypertension, although there was no significant difference in hypertension rates between the groups, choroidal thickness might have been affected by the hypertension [8]. Thus, the relationship between CIMT and choroidal thickness may not has been demonstrated clearly. In conclusion, these results may support that systemic vascular disorders such as atherosclerosis and cardiovascular disease can lead to structural changes in choroid and retinal ganglion cell layer. Therefore, such diseases should be considered for choroidal structure evaluation. Also, despite all limitations the present study can guide for the further studies with a larger cohort size to evaluate the relationship between CIMT and choroidal/retinal changes, and to use adapted OCT parameters for the evaluation of atherosclerosis and atherosclerotic diseases.

\section{References}

1. Nezu T, Hosomi N, Aoki S, Matsumoto M (2016) Carotid Intima-Media Thickness for Atherosclerosis. J Atheroscler Thromb 23(1): 18-31.
2. Grobbee DE, Bots ML (1994) Carotid artery intima-media thickness as an indicator of generalized atherosclerosis. J Intern Med 236(5): 567573 .

3. Li G, Hu R, Gu J, Wu HZ (2015) Relationship between carotid artery atherosclerosis and sulfatide in hypertensive patients. Genet Mol Res 14(2): 4840-4846.

4. Chae CU, Lee RT, Rifai N, Ridker PM (2001) Blood pressure and inflammation in apparently healthy men. Hypertension 38(3): 399403.

5. Tabatabaei MO, Fakhrzadeh H, Sharifi F, Mirarefin M, Arzaghi SM, et al. (2015) Effect of metabolic control on oxidative stress, subclinical atherosclerosis and peripheral artery disease in diabetic patients. J Diabetes Metab Disord 14: 84.

6. Fitch KV, Stavrou E, Looby SE, Hemphill L, Jaff MR, et al. (2011) Associations of cardiovascular risk factors with two surrogate markers of subclinical atherosclerosis: endothelial function and carotid intima media thickness. Atherosclerosis 217(12): 437-440.

7. Baldassarre D, Castelnuovo S, Frigerio B, Amato M, Werba JP, et al. (2009) Effects of timing and extent of smoking, type of cigarettes, and concomitant risk factors on the association between smoking and subclinical atherosclerosis. Stroke 40(6): 1991-1998.

8. Akay F, Gundogan FC, Yolcu U, Toyran S, Uzun S (2016) Choroidal thickness in systemic arterial hypertension. Eur J Ophthalmol 26(2): 152-157.

9. Sizmaz S, Küçükerdönmez C, Pinarci EY, Karalezli A, Canan H, et al. (2013) The effect of smoking on choroidal thickness measured by optical coherence tomography. Br J Ophthalmol 97(5): 601-604.

10. Esmaeelpour M, Brunner S, Ansari SS, Nemetz S, Povazay B, et al. (2012) Choroidal thinning in diabetes type 1 detected by 3-dimensional 1060nm optical coherence tomography. Invest Ophthalmol Vis Sci 53(11): 6803-6809.

11. Touboul PJ, Hennerici MG, Meairs S, Adams H, Amarenco P, et al. (2007) Mannheim carotid intima-media thickness consensus (2004-2006). An update on behalf of the Advisory Board of the 3rd and 4th Watching the Risk Symposium, 13th and 15th European Stroke Conferences, Mannheim, Germany, 2004, and Brussels, Belgium, 2006. Cerebrovasc Dis 23(1): 75-80.

12. Stein JH, Korcarz CE, Hurst RT, Lonn E, Kendall CB, et al. (2008) Use of carotid ultrasound to identify subclinical vascular disease and evaluate cardiovascular disease risk: a consensus statement from the American Society of Echocardiography Carotid Intima-Media Thickness Task Force. Endorsed by the Society for Vascular Medicine. J Am Soc Echocardiogr 21(2): 93-111.

13. Agladioglu K, Pekel G, Citisli V, Yagci R (2015) Choroidal thickness and retinal vascular caliber correlations with internal carotid artery Doppler variables. J Clin Ultrasound 43: 567-572.

14. Torres FS, Fuchs SC, Maestri MK, Fuchs FD, Oliveira MM, et al. (2013) Association between carotid intima-media thickness and retinal arteriolar and venular diameter in patients with hypertension: a crosssectional study. Atherosclerosis 229(1): 134-138.

15. Kang HM, Lee CS, Lee SC (2014) Thinner subfoveal choroidal thickness in eyes with ocular ischemic syndrome than in unaffected contra lateral eyes. Graefes Arch Clin Exp Ophthalmol 252: 851-852.

16. Mamikonyan VR, Gavrilenko AV, Galoyan NS, Kuklin AV, Abramyan AV, et al. (2015) Ocular blood flow and carotid artery malfunction. Vestn Oftalmol 131(2): 19-25. 
This work is licensed under Creative Commons Attribution 4.0 License DOI:-10.19080/JOJO.2017.04.555637
Your next submission with Juniper Publishers will reach you the below assets

- Quality Editorial service

- Swift Peer Review

- Reprints availability

- E-prints Service

- Manuscript Podcast for convenient understanding

- Global attainment for your research

- Manuscript accessibility in different formats

( Pdf, E-pub, Full Text, Audio)

- Unceasing customer service

Track the below URL for one-step submission https://juniperpublishers.com/online-submission.php 